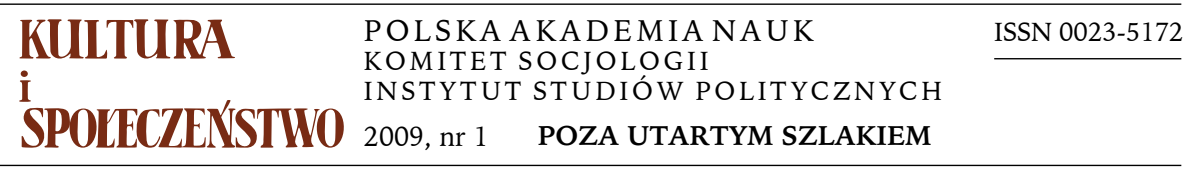

KRZYSZTOF TYSZKA

Uniwersytet Warszawski

\title{
CZY ŻYJEMY W EPOCE „ŚMIERCI UTOPII”?
}

W refleksji nad kondycją współczesnej kultury i życia społecznego wyraźnie obecne jest przekonanie o zmierzchu czy wręcz zaniku utopii. Diagnozę tę należy jednak rozpatrywać szerzej, w kontekście stwierdzeń mówiących o zaniku wszelkich całościowych form dyskursu społecznego. Proces ten związany był z traumatycznymi doświadczeniami drugiej wojny światowej i dwóch wielkich totalitaryzmów, które zdominowały pierwszą połowę XX wieku. Był to czas, w którym niewątpliwie najwyraźniej ukazała się siła utopii. Pojęcie to rozumiem $\mathrm{w}$ tym przypadku jako realizację (a w każdym razie próbę realizacji) całościowego i radykalnego przeobrażenia społeczeństwa wedle pewnego szczegółowego projektu. Próby te, co istotne, dokonywane były bez liczenia się z negatywnymi konsekwencjami społecznymi — zarówno wymiernymi, jak i niewymiernymi. Siła utopii przejawiała się więc w fakcie całkowitego podporządkowania realiów życia społecznego pewnej abstrakcyjnej idei. W tym to znaczeniu traktuje o utopii Karl Popper. Jest ona dla niego strategią zmiany społecznej dokonywanej w myśl zasady: najpierw określmy ostateczny Cel (ideał), a następnie dostosujmy do niego nasze działanie. Nie zważa się tu ani na zmienność wyzwań i realiów życia, ani na szczegółowe aspekty życia społecznego. Liczy się jedynie Cel i Całość, a nad przebiegiem owych przeobrażeń czuwa „inżynier” przekonany, iż odkrył wszelkie zakryte dotąd mechanizmy historii ${ }^{1}$. Tak rozumiana utopia czy, mówiąc za Popperem, inżynieria utopijna nie tylko niosła w sobie przemoc, ale także niszczyła podmiotowość ludzką, zdejmując $z$ jednostki odpowiedzialność za jej czyny. Działanie bowiem jawi się w tej per-

\section{Adres do korespondencji: ktyszka@uw.edu.pl}

1 Por. K. R. Popper, Spoteczeństwo otwarte $i$ jego wrogowie, tłum. H. Krahelska, Wydawnictwo Naukowe PWN, Warszawa 1993, t. 1, s. 182-185; por. K. R. Popper, Nędza historycyzmu, tłum. S. Amsterdamski, Wydawnictwo Naukowe PWN, Warszawa 1999, s. 72-75; K. R. Popper, Utopia a przemoc, w: K. R. Popper, Droga do wiedzy. Domysty i refutacje, tłum. S. Amsterdamski, Wydawnictwo Naukowe PWN, Warszawa 1999. 
spektywie wyłącznie jako emanacja dominujących nad człowiekiem wielkich procesów przebudowy świata.

Reakcją na te doświadczenia był zanik wielkich projektów intelektualnych śmiało rysujących nowy doskonały ład społeczny. Wizjonerstwo, naznaczone pragnieniem uszczęśliwienia ludzkości i usunięcia ze świata wszelkich niedoskonałości, budziło sprzeciw i nieufność. Możemy mówić tu o zaniku „utopii rekonstrukcji”, którym to mianem określa się wszelkie idee charakterystyczne dla ruchów rewolucyjnych czy, ogólnie, wszelkich ruchów społecznych stawiających sobie za cel zasadnicze przeobrażenie społeczeństwa. „[...] kryzys wiary $\mathrm{w}$ Postęp - pisze Roland Schaer - [...] prowadzi do pytania, które bez wątpienia było podstawą wszelkiego rodzaju utopii w ciągu wieków: o ścisły związek $z$ technologia, panowanie człowieka nad naturą i zachwyt, niekiedy fanatyczny, wobec instrumentalnego i mechanicznego rozumowania" 2 . Druga połowa XX wieku to czas wyraźnego odejścia od utopii akcentującej nieuchronność postępu rozumianego w kategoriach kumulatywnego rozwoju wiedzy i technologii. W latach pięćdziesiątych i sześćdziesiątych rozwinęła się teza o „końcu wieku ideologii” ${ }^{3}$. Jej autorzy — głównie Daniel Bell i Raymond Aron — głosili, że dobiegła końca epoka, w której życie społeczne i polityczne jest formowane przez wielkie systemy myślowe, projekty roszczące sobie pretensje do kształtowania całości życia społecznego. „Na Zachodzie, wśród intelektualistów, dawne namiętności wyczerpały się - pisał Bell. - Nowe pokolenie, bez istotnej pamięci tych dawnych debat i bez solidnej tradycji je wzmacniającej, odnajduje się szukając nowych celów w ramach społeczeństwa politycznego, które odrzuciło, mówiąc językiem intelektualnym, stare apokaliptyczne i chiliastyczne wizje" ${ }^{4}$. Miejsce ustabilizowanych systemów ideologicznych zajmuje mnogość idei i światopoglądów, z których żaden nie rości sobie prawa do dominacji. Miejsce ideologicznego systemu zajmuje postawa krytyczna wobec wszystkich gotowych formuł, skłaniająca człowieka do wątpienia i otwartości na różnorodność doświadczeń. Krytycyzm miał być tutaj antidotum na ideologiczny fanatyzm ${ }^{5}$.

Dojmujące doświadczenie zła niesionego przez wielkie projekty utopijnej inżynierii społecznej, które ze szczególną siłą doszły do głosu w minionym stuleciu, nie tylko ukształtowały ową postawę krytycyzmu i zwątpienia wobec wszelkich „wielkich projektów”, ale także przyniosły wyraźną krytykę utopijnych idei. Przenikliwy badacz i krytyk utopii Emil Cioran w myśleniu uto-

2 R. Schaer, Utopia: Space, Time, History, w: R. Schaer, G. Claeys (red.), Utopia: The Search for the Ideal Society in the Western World, The New York Public Library, New York 2000, s. 6.

${ }^{3}$ Mówiąc o zmierzchu ideologii i utopii używam tych pojęć w znaczeniu bardziej potocznym pewnych całościowych systemów interpretacji świata i projektów jego przeobrażenia. Nie odnoszę się w tym miejscu do, skądinąd istotnego rozróżnienia Karla Mannheima, który traktuje te dwa pojęcia jako swe przeciwieństwa. Do tego problemu wrócimy w dalszej części pracy.

${ }^{4}$ D. Bell, The End of Ideology, The Free Press of Glencoe, Glencoe Ill. 1960, s. 374.

5 Por. R. Aron, Opium intelektualistów, tłum. Cz. Miłosz, Muza, Warszawa 2000, s. 356. 
pijnym widzi nowożytną wersję pelagianizmu: doktryny, wedle której człowiek nie został dotknięty skutkami grzechu pierworodnego, jego zbawienie może się więc dokonać dzięki wewnętrznej doskonałości, bez aktu nadprzyrodzonej Łaski. To poszukiwanie dróg osiągnięcia zbawienia siłami wyłącznie ludzkimi przejawiało się więc $\mathrm{w}$ poszukiwaniu form doskonałego ładu społecznego, a w konsekwencji w poddaniu się jego zniewalającej mocy. Stanowiło, innymi słowy, źródło myślenia utopijnego. „Kiedy Chrystus zapewniał, że «królestwo Boże» nie jest $z$ «tego» ani $z$ «tamtego świata», lecz tkwi wewnątrz nas, $z$ góry przekreślał utopijne konstrukcje, w których każde «królestwo» jest z konieczności poza nami i bez żadnego związku z naszym głębokim «ja» albo z naszym jednostkowym zbawieniem - pisze Cioran. - Ale one tak bardzo nas naznaczyły, że oswobodzenia oczekujemy wciąż spoza nas, od biegu wypadków czy od dziejów zbiorowości. W ten sposób zarysował się Kierunek historii, moda na niego miała zastąpić modę na Postęp, nie wnosząc niczego nowego" 6 .

Krytyka utopizmu przejawiała się także w licznych „antyutopiach”, określanych niekiedy mianem „utopii negatywnych”. Ich autorzy: George Orwell, Aldous Huxley czy Jewgienij Zamiatin, ukazywali przerażającą wizję społeczeństwa, w którym każdy najdrobniejszy element życia indywidualnego i zbiorowego podlega odgórnej regulacji i kontroli. Jednostka zaś staje się jedynie całkowicie bezwolną „śrubką" w doskonałym mechanizmie nowego porządku.

Kwestia zaniku utopii we współczesnej refleksji społecznej widoczna jest wyraźnie zwłaszcza wówczas, gdy zwrócimy uwagę na pewien paradoks. Historia myśli utopijnej bowiem bardzo wyraźnie pokazuje, iż rozwój utopii związany był integralnie $z$ doświadczeniem kryzysu społecznego, przejawiającym się $\mathrm{W}$ poczuciu wyczerpania tradycyjnego porządku aksjologicznego i normatywnego, anachronizmie i niewydolności istniejących instytucji, słowem z przesileniem i wynikającą z niego potrzebą zmiany. Utopie stanowią wytwór przeświadczenia o konieczności dokonania zasadniczego przeobrażenia społeczeństwa. To one właśnie dawały niezbędny wówczas program całościowej przebudowy i wizję przyszłego ładu społecznego. Dwudzieste stulecie powszechnie było postrzegane jako „wiek kryzysu”. Diagnoza ta stanowiła niemal stały motyw w myśli bardzo wielu filozofów i badaczy życia społecznego, niezależnie od uznawanych przez nich postaw ideowych i światopoglądowych. Dość przypomnieć w tym miejscu pesymistyczne wizje „buntu mas” i wszechogarniającej „ochlokracji” niszczącej cały dorobek cywilizacji europejskiej, „nienasycenie" człowieka w pogoni za zaspokojeniem swych namiętności czy wreszcie zagubienie i wyalienowanie jednostki w świecie zdominowanym przez żądze władzy i posiadania. Wszystko to, zdawać by się mogło, powinno prowadzić do

${ }^{6}$ E. Cioran, Historia $i$ utopia, tłum. M. Bieńczyk, Instytut Badań Literackich, Warszawa 1997, s. $72-73$. 
uaktywnienia w człowieku skłonności do poszukiwania szczęśliwego świata. Tak się jednak nie stało. Minione stulecie wytworzyło zadziwiająco mało utopii. Zaważyły na tym niewątpliwie wszystkie wyżej wspomniane doświadczenia. Warto jednak zwrócić uwagę, iż diagnoza kryzysu, która towarzyszyła ludzkości w najróżniejszych epokach, w wieku XX przybrała postać szczególną. Kryzys ów bowiem okazał się nie - jak dotychczas - stymulatorem utopii, ale - przeciwnie - dotknął niejako ją samą. Wyczerpał zapał i zaangażowanie właściwe utopistom, w to miejsce wprowadził sceptycyzm i nieufność, przeniknięte przez dojmujące doświadczenie ambiwalencji postępu. Rozwój, jak wskazywano, niesie w sobie też koszty, przejawiające się w poczuciu niepewności, zagubienia i egzystencjalnej pustki.

Pragnę tu zwrócić uwagę na pewien symptom „śmierci utopii”, przejawiający się nie tyle $\mathrm{w}$ jej krytyce, ile $\mathrm{w}$ zmianie paradygmatu myślenia o życiu społecznym. Warto bowiem, jak sądzę, zastanowić się nad pytaniem, czy rzeczywiście mamy do czynienia z zanikiem utopii społecznych, czy też obserwujemy zasadnicze przeobrażenie myślenia utopijnego? Jeśli tak, to na czym polega jego specyfika? Z pytaniem tym zaś związany jest problem ogólniejszej natury. Czy może istnieć społeczeństwo bez jakiejś formy utopii, rozumianej czy to jako pewna wizja pożądanego ładu społecznego, czy też jedynie jako poszukiwanie „lepszego życia” bądź to w wymiarze społecznym, bądź indywidualnym.

Zacznijmy od dokładniejszego przyjrzenia się samemu fenomenowi utopii. Przedstawialiśmy ją dotąd w sposób bliski rozumieniu Poppera - jako pewien całościowy projekt dogłębnej przebudowy społeczeństwa, oparty na przekonaniu o istnieniu pewnego celu ostatecznego, który staje się przedmiotem bezwzględnego dążenia do urzeczywistnienia. Warto jednak zwrócić uwagę na inne interpretacje tego zjawiska, w których złagodzeniu ulega radykalnie negatywna ocena utopii i ostre jej przeciwstawienie innym formom refleksji społecznej.

Znany francuski socjolog Alain Touraine w utopii widzi kluczowy element dyskursu społecznego właściwy epoce nowoczesności. Nie ma ona charakteru „ucieczki” od realnie istniejącej rzeczywistości w świat iluzji czy marzeń. Stanowi istotną formę namysłu nad światem. Jest zatem czynnikiem tworzącym porządek społeczny, który wyznacza cele działania i formy, jakie aktywność społeczna winna przyjmować. Słowem proponuje on usunięcie przeciwstawienia rzeczywistości i utopii, twierdząc, że społeczeństwo jako takie bez utopii istnieć nie może. „Będę proponował - pisze Touraine - aby utopię definiować poprzez szczególną treść, która przeciwstawia ją innym formom marzeń, oczekiwań czy demaskacji, które wyrastają, kiedy człowiek traci nadzieję na raj w jakimś świecie zewnętrznym, a zatem szuka go na ziemi. Utopia daje formę idei istoty ludzkiej jako osoby w pełni społecznej, która nie ma ani nadprzyrodzonej, ani indywidualnej realności, nawet jeśli porządek społeczny często postrzegany jest jako część szerszego porządku naturalnego. Utopia jest apelem do społeczeństwa, które kształtowało się narzucając wolność bądź niewolę swoim członkom, aby odsunąć wszelkie niespołeczne zasady legity- 
mizacji porządku społecznego" 7 . Podobnie Robert Nisbet zwraca uwagę, iż utopia stanowi nieodzowny element także współczesnego świata, zwłaszcza $\mathrm{w}$ warunkach rozwoju technologicznego i demokracji ${ }^{8}$. Utopia widziana $z$ tej perspektywy stanowi odpowiedź na procesy sekularyzacyjne. W miejsce religijnie usankcjonowanych celów czy projektów ładu społecznego pojawia się utopia rozumiana jako zespół norm i idei ład ów kształtujących i utrwalających. Inaczej mówiąc, jest ona odpowiedzią na odwieczne dążenia człowieka do osiągnięcia doskonałej harmonii i szczęścia, które dotychczas były zaspokajane przez doświadczenie religijne i wizje eschatologiczne. $Z$ tego punktu widzenia interesująca wydaje się analiza porównawcza religijnie ukształtowanej eschatologii i utopii. Obie formy są ukierunkowane na poszukiwanie ładu doskonałego. Jeżeli jednak ład mesjański jest niejako „nałożony” na człowieka „z góry”, to w utopiach mamy do czynienia z przekonaniem, że wszystko jest podporządkowane świadomej woli ludzkiej ${ }^{9}$.

W podobny sposób rozumie fenomen utopii Karl Mannheim, który — jak zostało wcześniej wspomniane - widzi w niej główny czynnik rozwoju społecznego. Utopia dlań to wszelkie przejawy krytycznej refleksji nad istniejącym porządkiem społecznym, stanowiącej impuls zmiany. „Utopijna jest taka świadomość - pisze Mannheim - która nie pokrywa się z otaczającym ją «bytem». Ta niezgodność objawia się zawsze w ten sposób, że taka świadomość w przeżywaniu, myśleniu i działaniu orientuje się na czynniki, których ów «byt» jako urzeczywistniony nie zawiera. [...] Utopijną będziemy nazywać tylko taką "transcendentną wobec rzeczywistości» orientację, która przechodząc do działania, jednocześnie częściowo lub całkowicie rozsadza istniejący w danym czasie porządek bytu" ${ }^{10}$. Przeciwstawiając utopię ideologii, Mannheim wskazuje na jej integralny związek z praktyką społeczną. Nie jest ona wytworem czystej spekulacji, lecz wyrasta z czynu i do czynu prowadzi. Można więc powiedzieć, że myślenie utopijne stanowi nieodłączny element życia społecznego, jest wszechobecne i trwałe w tym sensie, iż przybiera formę krytyki społecznej. Ta zaś właściwa jest człowiekowi jako istocie rozumnej i kreatywnej. „Wszystkie utopie — pisze Georg Picht — rodzą się z krytyki stanu aktualnego i odwrotnie, założeniem każdej krytyki stosunków politycznych i społecznych jest wskazanie przynajmniej możliwości lepszego stanu całościowego" ${ }^{11}$. Z tego punktu widzenia dokonuje on rozróżnienia na „utopię konkretną” i „utopię krytyczną”. Przykładem tej pierwszej są wszelkie całościowe projekty rzeczywistości społecznej, ukazujące taki czy inny model świata doskonałego: na przykład utopia Morusa czy Campanelli. Zostały one zastąpione przez „utopie krytyczne”, które

\footnotetext{
${ }^{7}$ A. Touraine, Society as Utopia, w: R. Schaer, G. Claeys (red.), Utopia, cyt. wyd., s. 18.

8 Por. R. A. Nisbet, Community and Power, Oxford University Press, New York 1962, s. xvii.

9 Por. M. Buber, Paths in Utopia, Beacon Press, Boston 1958, s. 8.

10 K. Mannheim, Ideologia i utopia, tłum. J. Miziński, Aletheia, Warszawa 2008, s. 229.

11 G. Picht, Technika $i$ utopia, tłum. K. Wolicki, w: G. Picht, Odwaga utopii, PIW, Warszawa 1981, s. 199.
} 
tym się charakteryzują, iż nie usiłują konstruować wizji szczęśliwych światów, lecz stanowią źródło krytycznej refleksji nad rzeczywistością społeczną ${ }^{12}$. Także Krishan Kumar, jeden $z$ bardziej znanych badaczy tej problematyki, postrzega utopię jako jeden $z$ gatunków myśli społecznej, a jego specyficzną cechą jest krytycyzm. „Utopia - pisze - jest jednym z nurtów badania społeczeństwa. Różni się ona w swej formie od innych nurtów, a jej oczywisty, uświęcony zwyczajem cel czyni ją odmienną od innych, bardziej konwencjonalnych ujęć. Nigdy jednak nie przestała siebie postrzegać jako formę krytycznej i konstruktywnej analizy społecznej" ${ }^{13}$. Krytyka ta ma charakter integralny. Utopia krytyczna formułuje bowiem przede wszystkim pewien teoretyczny schemat krytyki, który daje narzędzia służące jej praktycznemu zastosowaniu. Stanowi także pewną samokrytykę, wskazując na różnice między utopią a rzeczywistością. Inaczej mówiąc, kategoria utopii funkcjonuje tutaj nierozdzielnie $z$ pewną wizją społeczeństwa jako rzeczywistości poddanej nieustannym zmianom i przeobrażeniom. U źródeł tych zmian tkwi zaś mechanizm krytyki, rewizji, poszukiwania rozwiązań lepszych od tych aktualnie istniejących. Przy czym krytyce tej poddana zostaje sama ta krytyczna refleksja, której diagnozy i rozwiązania nieustannie podlegają presji ze strony konkurencyjnej krytyki i weryfikowane są w społecznej praktyce. „Nieustannie i nieuchronnie przewodzą nam utopie nieuświadamiane i przeto nie podatne na kontrolę - czytamy dalej u Pichta. — Każdy, kto podejmuje decyzje, kto działa lub planuje, chce zawsze coś ulepszyć. Ma więc przed oczyma stan, który w porównaniu z teraźniejszością jest utopijny" ${ }^{14}$.

Rozróżnienie między utopią „konkretną” a „krytyczną” pozwala dostrzec zasadniczy tutaj problem racjonalności. W potocznym odczuciu bowiem skłonni jesteśmy widzieć w myśleniu utopijnym przejaw skrajnego irracjonalizmu. Utopia jawi się jako mrzonka, fantazja, przejaw bujnej wyobraźni jej twórców. Stanowisko to $\mathrm{w}$ wysokim stopniu odpowiada właśnie owemu nurtowi „utopii konkretnych". Świat nowy, radykalnie odmienny od istniejącego, był przedstawiany jako alternatywa domagająca się realizacji. Nie stawiano jednak pytania o możliwości powodzenia tego przedsięwzięcia i jego społeczne konsekwencje. Zupełnie inaczej jest w przypadku „utopii krytycznych”. Nieprzypadkowo Bauman określa je mianem „utopii aktywnych”. Mechanizm krytyki wpisany niejako $\mathrm{w}$ ich wewnętrzną logikę nakazuje poddawać wszelkie elementy otaczającej nas rzeczywistości racjonalnemu namysłowi i na tej podstawie formułować projekty zmiany. Pokazuje to utopię „nie jako znak wzrastającego irracjonalizmu i odejścia od zasad rozumu, lecz jako miarę żywotności i twórczego wigoru epoki. [...] Brak utopii - pisze Bauman - tworzy pustkę, mętną bezdenną otchłań zamiast łagodnego rozprzestrzeniania się teraźniejszości” ${ }^{15}$.

\footnotetext{
12 Por. tamże, s. 202.

13 K. Kumar, Utopianism, University of Minnesota Press, Minneapolis 1991, s. 41.

14 G. Picht, Technika..., cyt. wyd., s. 199.

15 Z. Bauman, Socialism: The Active Utopia, George Allen \& Unwin, London 1976, s. 36.
} 
Seyla Benhabib z kolei w swej książce poświęconej teorii krytycznej, wyróżniając dwie wizje polityki: „politykę spełnienia” i „politykę przeobrażenia”, wskazuje normy i utopie jako kategorie dla nich kluczowe. „Polityka spełnienia pisze - wyobraża sobie, że społeczeństwo przyszłości osiąga w sposób bardziej odpowiedni to, co obecne społeczeństwo pozostawiło niedokończonym. [...] Polityka przeobrażenia kładzie nacisk na wyłonienie się jakościowo nowych potrzeb, relacji społecznych i sposobów stowarzyszania się, które rozwierają utopijny potencjał $\mathrm{w}$ ramach tego, co stare" 16 .

Fenomen utopii ukazuje nam więc pewne fundamentalne napięcie właściwe życiu społecznemu i egzystencji ludzkiej. $Z$ jednej strony bowiem realizacja utopijnych projektów niesie istotne zagrożenie dla istniejącego porządku społecznego. $Z$ drugiej strony jednak nie można pominąć faktu konstruktywnej jej funkcji. Paul Tillich mówi w tym kontekście o „prawdzie utopii”, wskazując, iż „wyraża ona istotę człowieka, wewnętrzne cele jego egzystencji”. Proponuje on odróżnienie zewnętrznego (społecznego) aspektu utopii od jej wymiaru wewnętrznego (osobistego). „Utopia pokazuje — pisze dalej Tillich - kim człowiek jest $\mathrm{w}$ swej istocie i co powinien mieć jako telos swojej egzystencji. Każda utopia jest manifestacją tego, co człowiek posiada jako wewnętrzny swój cel i co musi posiadać dla spełnienia się jako osoba" ${ }^{17}$. Analizując więc fenomen utopii, winniśmy patrzeć nie tylko na jej „efekt końcowy”: sposoby jej wprowadzenia w życie i skutki, do jakich strategia ta prowadzi. Nie mniej istotne jest spojrzenie na jej źródło. Co mówi ona o człowieku, o społeczeństwie i kulturze, w której żyje, o jego aspiracjach i dążeniach. „Każda utopia jest antycypacją ludzkiego spełnienia. [...] Bez tej uprzedzającej wynalazczości niezliczone możliwości pozostałyby niezrealizowane. [...] Teraźniejszość dla ludzi nieposiadających utopii jest nieuchronnie ograniczona i, podobnie, kultury, które nie posiadają utopii, pozostają uwięzione w teraźniejszości i szybko upadają w przeszłość; dla teraźniejszości w pełni ożywczym może być tylko napięcie między przeszłością a przyszłością. Na tym polega owocność utopii jej zdolność otwierania możliwości" ${ }^{18}$.

Utopie pozwalają nie tylko na poznanie ludzkich dążeń, aspiracji i namiętności. Stanowią także swego rodzaju mapę, dzięki której możliwe jest wyznaczenie kierunków przeobrażeń społecznych. Mówią nam one nie tylko o tym, ,jak powinno być”, ale także, co należy zrobić, by stan ten osiągnąć. W tym kontekście Leszek Kołakowski dokonuje bardzo istotnego rozróżnienia dwóch aspektów utopii: projektu politycznego i drogowskazu. Odwołując się do filozofii Kanta, mówi o idei konstytutywnej i regulatywnej. O ile uto-

16 S. Benhabib, Critique, Norm, and Utopia: A Study of the Foundations of Critical Theory, Columbia University Press, New York 1986, s. 13.

17 P. Tillich, Critique and Justification of Utopia, w: Utopias and Utopian Thought, F. E. Manuel (red.), Souvenir Press, London 1973, s. 296.

18 Tamże, s. 297-298. 
pia rozumiana w tym pierwszym aspekcie stanowi zagrożenie dla wolności i suwerenności jednostki, próbując podporządkować ją arbitralnie sformułowanemu projektowi, o tyle utopia o charakterze idei regulatywnej jest wręcz niezbędna dla prawidłowego rozwoju jednostki i społeczeństwa. Wskazuje ona bowiem potencjalne kierunki i cele owego rozwoju, mówi, jak można i należy je osiągnąć, a w ten sposób pobudza jednostkę do twórczego działania, społeczeństwo zaś do nieustannej mobilności. „Mapa” wyznaczona przez utopię nie stanowi jednak schematu działania. Jest ona swoistą pomocą $\mathrm{w}$ poruszaniu się po meandrach życia, nie usiłuje jednak formułować gotowych rozwiązań czy projektów. Wizja zbudowania przez człowieka doskonałego ładu społecznego staje się w tym ujęciu pewną inspiracją i wskazówką, która akceptuje autonomię jednostki i uznaje możliwość wyboru różnych dróg podążania do celu ${ }^{19}$. Na podobny aspekt fenomenu utopii zwraca też uwagę Kumar: „Pragnienia i projekty, harmonia i nadzieja: z pewnością prowadzi to do tworzenia utopii, tak jak być może innej społecznej i politycznej filozofii. Ich szczególny wkład jest zatem niewątpliwie ważny w jej tworzeniu. Utopia jednak nie tylko na nowo łączy te elementy. Ma ona swą własną wynalazczość. Kiedyś utrwalona, dziś dostarcza mapę zupełnie różnych możliwości namysłu nad kondycją ludzką" 20.

Przyjęcie tej perspektywy teoretycznej pozwala inaczej spojrzeć na miejsce utopii w refleksji socjologicznej i społecznej. Klasyczne utopie ukazujące model idealnego ładu i pełnej harmonii relacji międzyludzkich w tej perspektywie będą stanowić jedynie pewien fragment, w istocie rzeczy, dość wąski, w ramach refleksji naznaczonej śladami utopii. Stanowią one przejaw ujmowania tego fenomenu właśnie jako idei konstytutywnej. Począwszy od dzieła Morusa poprzez wizje teoretyków postępu i projekty socjalistów utopijnych - wszystkie one dawały pewien gotowy projekt rzeczywistości. Uznanie w utopii nade wszystko elementu konstruktywnej krytyki i czynnika regulacji ładu społecznego ukazuje wymiar utopizmu wszędzie tam, gdzie dochodzi do głosu przekonanie o możliwości zasadniczego przeobrażenia stosunków gospodarczych, społecznych i politycznych. Formułowane jest ono jednak jako ukazanie możliwości i sposobów owej zmiany: służy inspiracji, nie rości sobie jednak prawa do inicjowania jakkolwiek rozumianej „nowej epoki” czy „wielkiego przełomu”. Nie mamy tu więc do czynienia z krytykowaną przez Poppera „inżynierią utopijną". Wskazanie tego, ,jak być powinno" i co jest dostępne ludzkim możliwościom, nie oznacza bynajmniej roszczeń do sformułowania i narzucenia całościowego projektu nowego ładu.

Analiza twórczości szkoły krytycznej pozwala nam szczególnie wyraźnie dostrzec ten aspekt utopizmu. Wizja człowieka uwolnionego od dominacji dóbr materialnych, którego cele wyznaczają potrzeby duchowe i estetyczne, nie zaś

19 Por. L. Kołakowski, Śmierć utopii na nowo rozważona, tłum. A. Pawelec, w: L. Kołakowski, Moje stuszne poglądy na wszystko, Znak, Kraków 1999.

20 K. Kumar, Utopianism, cyt. wyd., s. 19. 
wszechobecność ekonomicznej kalkulacji, odbudowanie relacji społecznych nie zapośredniczonych przez mechanizmy mediów i reklamy — wszystkie te wątki, tak charakterystyczne dla twórczości Fromma, Marcusego czy Habermasa, stanowią właśnie ów utopijny drogowskaz wyłaniający się z krytyki istniejącego porządku. $Z$ tego punktu widzenia wyraźny staje się pozytywny aspekt utopii. Niezależnie bowiem jak ocenimy te diagnozy i płynące zeń propozycje, przesłanie to służy wyłącznie „budowaniu”, w tym sensie, że otwiera przed człowiekiem horyzonty działania i twórczych przeobrażeń. Otwiera perspektywy zmiany, lecz jej nie narzuca i nie przeprowadza. Taką właśnie sytuację ma na myśli Kumar, gdy pisze, iż „cała teoria społeczna aspiruje do bycia utopijną”. Dalej zaś stwierdza: „Utopijne koncepcje są nieodzowne w polityce i w postępie, bez nich polityka jest pustką pozbawioną duszy" 21 .

Na czym więc polega kryzys czy, jak niektórzy mówią, „śmierć utopii”? $\mathrm{W}$ świetle tego, co zostało dotychczas powiedziane, problem ten wydaje się znacznie bardziej złożony niż negatywne doświadczenia inżynierii utopijnej, których doznała ludzkość w minionym stuleciu. Wszak rozumienie utopii społecznej, jak starałem się wykazać, nie musi ograniczać się do takiego wymiaru, w jakim ujmował ją choćby Popper. Źródła tego procesu muszą tkwić głębiej aniżeli tylko w doświadczeniach historycznych. Diagnoza kryzysu utopii odnosi się zatem nie tylko do utopii, które Jeffrey Alexander określił mianem „totalizujących”, czyli takich właśnie „projektów” ładu społecznego, które uznają się za optymalne i tym samym ostateczne ${ }^{22}$. Problem ten odnosi się do znacznie szerszego wymiaru myślenia utopijnego, który nazwaliśmy „krytycznym”. Oznacza to zatem podważenie pewnej fundamentalnej właściwości człowieka jako gatunku, szczególnie akcentowanej zarówno przez tradycję Oświecenia, jak i nurt krytyczny, tradycję tę rewidujący — właściwości polegającej na poszukiwaniu w miejsce „tego, co jest”, tego, „jak być powinno”. Bardzo dobrze oddaje to jeden z głównych przedstawicieli teorii krytycznej, Herbert Marcuse, gdy pisze: „Człowiek zaczął organizować rzeczywistość zgodnie z postulatami swej wolnej, rozumnej myśli, zamiast po prostu przystosowywać myśli do istniejącego porządku i przyjętych wartości. Człowiek jest istotą myślącą. Rozum jego pozwala mu uświadomić sobie własne możliwości i możliwości, jakie istnieją W jego świecie. Dlatego nie jest bynajmniej niewolniczo zależny od faktów $\mathrm{i}$ istniejącego stanu rzeczy, jest zdolny do podporządkowania ich wyższemu kryterium, kryterium rozumu" 23 . Kryzys utopii oznacza tu zatem nie tyle odrzucenie pewnej strategii przeobrażenia świata, ale całej postawy duchowej i intelektualnej człowieka.

21 Tamże, s. 88, 95

22 Por. J. C. Alexander, Siła utopii $i$ utopia naprawy obywatelskiej, tłum. P. Sadura, w: Wspótczesne teorie socjologiczne, t. 1, A. Jasińska-Kania i in. (red.), Scholar, Warszawa 2006, s. 439-441.

$23 \mathrm{H}$. Marcuse, Rozum i rewolucja. Hegel a powstanie teorii społecznej, tłum. D. Petsch, Książka i Wiedza, Warszawa 1966, s. 10. 
Jakie przyczyny leżą u podstaw tego tak istotnego przeobrażenia? Pragnę rozważyć ten problem w kontekście coraz bardziej rozpowszechnionego współcześnie nurtu, zwanego postmodernizmem bądź ponowoczesnością. Twierdzę bowiem, że ta wizja jednostki i ładu społecznego, którą sformułowali przedstawiciele tej filozofii, w zasadniczy sposób podważa ów „krytyczny” wymiar myślenia i działania jednostki, a tym samym całego porządku społecznego. Postmodernistyczna wizja społeczeństwa eliminuje zarówno „totalizm” w przyjętym tutaj znaczeniu, jak i „krytycyzm”. Przyjrzyjmy się więc bliżej owemu antyutopijnemu mechanizmowi ponowoczesności.

Epoka określana tym mianem rysuje się jako czas, w którym wszelkie całościowe wizje i projekty przeobrażenia społeczeństwa ustąpiły miejsca niezliczonym cząstkowym zmianom, pozbawionym jasno określonego celu oraz odniesienia do aksjologicznego i normatywnego porządku. W świecie tym nie ma więc miejsca na jakąkolwiek systemowość, która niewątpliwie cechuje każdą społeczną utopię. Obecnie mówi się o „zaniku wielkich narracji”, czyli wszelkich całościowych form dyskursu społecznego. „[...] za "postmodernistyczną" uznajemy nieufność do metanarracji [...] - pisał Jean-François Lyotard. - Wyjściu z użycia metanarracyjnych środków uprawomocnienia dokładnie odpowiada kryzys filozofii metafizycznej [...]. Funkcja narracyjna traci swoje funktory: wielkiego bohatera, wielkie zagrożenia, wielkie przedsięwzięcia i wielki cel" 24 . Rzeczywistość społeczna jawi się jako przestrzeń zdominowana przez niemożliwe do przewidzenia jednostkowe działania, podobne do ruchu atomów, w których niepodobna zauważyć żadnego ponadindywidualnego sensu i celowości. W innej swej książce Lyotard wyjaśnia, iż ów zanik metanarracji ma swe źródło w zarzuceniu wszelkich dążeń zarówno do uprawomocnienia istniejącego ładu społecznego, jak i sformułowania „Idei czekającej na realizację". Miejsce jednej wielkiej Idei zajmują miliony indywidualnych interesów i celów stanowiących „osnowę życia codziennego". Nie ma jednak żadnych podstaw, by którekolwiek z nich uznać za najbardziej wartościowe i nadrzędne, a przez to dominujące ${ }^{25}$. Konsekwencją tego procesu jest zanik wszelkich jasno określonych kierunków zmiany społecznej. Inaczej mówiąc, życie społeczne $\mathrm{w}$ tej perspektywie przestaje tworzyć jakkolwiek rozumianą całość. Nie stanowi ani spójnego organizmu, ani też jedności uzupełniających się nawzajem przeciwieństw. Pytanie, ku czemu ono zmierza, jaki jest cel zmian i jakie ich konsekwencje, całkowicie traci sens. „Z rozpadu wielkich Narracji [...] - pisze Lyotard - wynika to, co niektórzy analizują jako rozpuszczenie się więzi społecznych i przejście od społecznych zbiorowości do stanu

24 J.-F. Lyotard, Kondycja ponowoczesna. Raport o stanie wiedzy, tłum. M. Kowalska, J. Migasiński, Fundacja Aletheia, Warszawa 1997, s. 20.

25 Por. J.-F. Lyotard, Postmodernizm dla dzieci. Korespondencja 1982-1985, tłum. J. Migasiński, Fundacja Aletheia, Warszawa 1998, s. 30-32. 
masy złożonej $\mathrm{z}$ indywidualnych atomów wprawianych $\mathrm{w}$ absurdalne ruchy Browna" 26.

Zagadnieniem $z$ naszego punktu widzenia najbardziej znaczącym jest więc ukazanie życia społecznego w zupełnie innej perspektywie. Nie istnieje bowiem żaden "modelowy” system więzi społecznych, gdyż te stały się we współczesnym świecie iluzją. Zygmunt Bauman pokazuje w swych pracach fundamentalne przeobrażenie charakteru więzi społecznych, a tym samym modelu społeczności ludzkich. Zatraciły one postać względnie trwałej struktury. Współczesna egzystencja człowieka przypomina koczowiska, punkty, w których zatrzymuje się on tylko na chwilę w nieustannym poszukiwaniu miejsca kształcenia, pracy, rozrywki i zamieszkania. Więzi międzyludzkie kształtowane są na podstawie pewnych aktualnie istotnych symboli czy konkretnych interesów. Człowiek ponowoczesny nie jest nigdzie zakorzeniony, jest nieustannie w ruchu, zarówno tym fizycznym, jak i duchowym.

To przeobrażenie społecznej egzystencji człowieka jest jedynie pewnym aspektem znacznie głębszych procesów. Perspektywa ponowoczesna odrzuca bowiem taką wizję świata, w której istnieje jakakolwiek trwałość i systemowość. Rzeczywistość w tym ujęciu jest zawsze „płynna”, a tym samym pozbawiona wszelkiego wewnętrznego ładu i harmonii. Życie społeczne zatem charakteryzuje się nie tylko zanikiem wszelkich trwałych więzi, ale także nieokreślonością i nieustanną zmiennością perspektywy egzystencji ludzkiej. Nic nie jest już raz na zawsze dane i nic nie jest oczywiste. Postawa ta prowadzi do wytworzenia się wszechobecnego poczucia tymczasowości i niepewności. Stały się one kluczową cechą ponowoczesnej kondycji człowieka. „Zjawiskiem nowym $\mathrm{w}$ ponowoczesnej odmianie niepewności (samej przez się nie będącej wszak doznaniem bez precedensu w świecie, który ma za sobą doświadczenia nowoczesnej ery) jest to także, że nie postrzega się jej już jako przykrości chwilowej, którą przy odpowiednim staraniu można będzie złagodzić lub nawet usunąć bez śladu. Swiat ponowoczesny - pisze Bauman - przymierza się do ewentualności życia z niepewnością na stałe, do warunków na zawsze już niepewnych, i to z taką niepewnością, jakiej zredukować żadną miarą się nie da" 27 . Wszechobecna niepewność i tymczasowość oznacza zasadnicze przeobrażenie interpretacji świata społecznego i rozumienia zachodzących $\mathrm{w}$ nim procesów. Bauman w tym kontekście zwraca uwagę na bardzo istotne przeobrażenie kategorii wieloznaczności. Dążeniem kultury jest zbudowanie pewnego ładu społecznego. Ów ład dotychczas był postrzegany jako istnienie kanonu kryteriów poznawczych i etycznych. Ponowoczesność natomiast zastępuje ład wieloznacznością. Ład w tej perspektywie nie jest nigdy czymś danym, jest zawsze czymś tymczasowym, wyłaniającym się ze stanu permanentnego chaosu. Chaos właśnie staje się nie-

${ }^{26}$ J.-F. Lyotard, Kondycja ponowoczesna, cyt. wyd., s. 59.

27 Z. Bauman, Ponowoczesność jako źródto cierpień, Sic!, Warszawa 2000, s. 43-44. 
usuwalnym elementem świata społecznego i czynnikiem kreującym kształt rzeczywistości. Uznanie chaosu jako podstawowego mechanizmu życia społecznego prowadzi tedy do zaniku formułowania wszelkich całościowych projektów społecznych czy ukazywania dróg rozwoju społecznego. Bauman mówi w tym kontekście o „obumieraniu pędu do rozwiązań ostatecznych” 28 . Ponowoczesna refleksja na temat życia społecznego zdaje się nie dostrzegać potrzeby poszukiwania jakiegokolwiek modelu ładu społecznego. Uchylone niejako zostały pytania: jak powinno być urządzone społeczeństwo, wedle jakich kryteriów powinny być dokonywane procesy zmiany społecznej i jaki cel zmianom tym ma towarzyszyć. Społeczeństwo ponowoczesne nie ma żadnego jednoznacznego celu, gdyż niepodobna takowego wskazać. Bauman zauważa, iż „coraz więcej $\mathrm{w}$ świecie sił zainteresowanych [...] w trwaniu i pogłębianiu się zróżnicowania, niedookreślenia, zagmatwania i nieuporządkowania $[\ldots] " 29$.

W kontekście tego, co zostało powiedziane, rodzi się pytanie, czy twierdzenie o „śmierci utopii” jest uprawnione. Czy filozofia postmodernistyczna dokonała jej unicestwienia czy jedynie istotnego przeobrażenia, zmiany jej formy i miejsca w społecznym i intelektualnym dyskursie. Skoro bowiem żyjemy dziś w świecie, w którym więzi społeczne już nie istnieją, bądź przybrały formę skrajnie nieokreśloną i krótkotrwałą, to faktycznie bardzo trudno doszukiwać się jakichś trwałych form społecznej krytyki, a tym bardziej „totalnych” projektów. Czy jednak ów aspekt krytyki zanikł, czy uległ znaczącemu przesunięciu ku innemu obszarowi refleksji? Wydaje się bowiem, że przejawów owej refleksji krytycznej, a tym samym myślenia utopijnego, należy szukać w wymiarze życia jednostkowego, nie zaś społecznego. Inaczej mówiąc, utopia przestała być utopią społeczną, czyli wizją nowego lepszego ładu społecznego, a stała się sposobem poszukiwania nowych dróg zaspokojenia potrzeb jednostki. Można powiedzieć, że wszelkie „wielkie narracje” niosły w sobie ów element utopi$\mathrm{zmu}, \mathrm{w}$ tym sensie, iż zakładały istnienie Prawdy — optymalnego modelu ładu społecznego, który - wcielony w życie - usunie ze świata zło. Potrzebny był jedynie ktoś, kto prawdę tę odkryje i przekaże innym. Mogła ona przybierać postać religijnej czy quasi-religijnej eschatologii, mogła odwoływać się do praw historii czy organicystycznego modelu świata przyrody, zawsze jednak niezbędny był nauczyciel, prawodawca, odkrywca, który staje się przewodnikiem ludzkości. Z tego punktu widzenia ponowoczesny upadek „wielkich narracji” jest też upadkiem utopii, a dokładnie pewnego ich typu, który Jerzy Szacki określa mianem utopii apollińskiej. Utopie te odwołują się do pewnych trwałych reguł, immanentnie istniejącego porządku świata, który starają się odkryć i wcielić w życie. Postmodernistyczna wizja świata nie usuwa jednak utopii ze społecznej refleksji, lecz tworzy fundament pod całkowicie inny ich rodzaj, który — za

28 Por. tamże, s. 26.

29 Tamże, s. 27. 
Jerzym Szackim — określić możemy mianem dionizyjskich ${ }^{30}$. Charakteryzują się one właśnie tym, że źródeł naprawy rzeczywistości społecznej doszukują się nie w istnieniu Prawdy czy jakiegoś ładu, do którego należy powrócić czy od podstaw go zbudować. Nowy człowiek i nowy świat możliwy jest tylko poprzez stworzenie warunków do nieskrępowanej ekspresji każdej jednostki, odkrycia i wyrażenia własnej prawdy i własnego wyobrażenia ideału dobrego życia. Innymi słowy, „utopia dionizyjska” związana jest integralnie z kulturą indywidualizmu. Warto więc zastanowić się nad kształtem owej „indywidualistycznej" utopii. Czy ten element współczesnej kultury w ogóle można nazwać utopią, a jeśli tak - to dlaczego?

Przede wszystkim należy w tym miejscu zwrócić uwagę na dwa źródła filozoficzne, a w konsekwencji dwojakiego rodzaju typy indywidualizmu. Jeden z nich korzeniami sięga twórczości Locke’a, Hume’a i Mandeville’a, kontynuowany jest przez Smitha, Tocqueville'a i Actona. Uznaje się tu niezbywalną podmiotowość jednostki oraz jej praw do swobodnego działania i rozwoju. Człowiek jednak nie jest postrzegany jako istota zdolna samodzielnie poznać otaczający ją świat i nad nim zapanować. Wiedza o świecie i związany z nią rozwój w wymiarze jednostkowym i społecznym możliwy jest tylko dzięki wzajemnej kooperacji i współdziałaniu jednostek. Tak rozumiany indywidualizm skierowany jest przeciwko wszelkiego rodzaju teoriom kolektywistycznym, widzącym w społeczeństwie byt sui generis, jednostki zaś podporządkowującym dominującym mechanizmom. Indywidualizm - jak pisze Friedrich von Hayek — „głosi [...], że jedyną drogą do zrozumienia zjawisk społecznych jest zrozumienie działań podejmowanych przez jednostki, działań nakierowanych na innych ludzi i uzależnionych od ich oczekiwanego zachowania" 31 . Indywidualizm jawi się tu więc nie tylko jako pewna idea czy konstrukt teoretyczny. Jest to nade wszystko cały syndrom postaw psychologicznych i etycznych. To tu należy szukać źródeł wszelkich teorii wskazujących na autonomię i wolność jednostki. Jak pisze Peter Berger: „[...] «indywidualizm», nawet w zakresie, $w$ jakim jest ideą (a niewątpliwie jest również ideą), ma zarówno aspekt poznawczy, jak i normatywny, wyraża jakieś zdanie o naturze istot ludzkich: Są one mianowicie bytami jednostkowymi ponad i poza wszelką identyfikacją zbiorową. Ale zakłada również, że istnieją moralne konsekwencje tego faktu: Istoty ludzkie mają pewne prawa jako jednostki, nie tylko niezależnie, ale nawet (a w istocie - głównie) w opozycji do zbiorowości, do której mogą należeć" 32 . W podobnym duchu wypowiada się Steven Lukes, który nadaje indywidualizmowi wymiar przede wszystkim etyczny: „[...] nie ma wątpliwości — pisze

\footnotetext{
30 Por. J. Szacki, Spotkania z utopia, Sic!, Warszawa 2000, s. 218.

31 F. Hayek, Indywidualizm i porządek ekonomiczny, tłum. G. Łuczkiewicz, Znak, Kraków 1998, s. 13.

32 P. L. Berger, Rewolucja kapitalistyczna. Pięćdziesiąt tez o dobrobycie, równości $i$ wolności, tłum. Z. Simbierowicz, Oficyna Naukowa, Warszawa 1995, s. 166.
} 
— że historycznie abstrakcyjne pojęcie jednostki oznaczało wielki moralny postęp. Był to decydujący krok w kierunku uniwersalistycznej etyki, gdy istoty ludzkie zaczęły być postrzegane jako posiadacze określonych praw i roszczeń, po prostu na mocy bycia człowiekiem" 33 .

Drugi typ indywidualizmu wyrasta $z$ tradycji filozofii kartezjańskiej. Zakłada ona, że każda jednostka ma możliwość rozumowego ogarnięcia świata. Inne jednostki są zbędne do jej intelektualnego i moralnego rozwoju. Wszyscy wszak mamy dostęp do Rozumu, który umożliwia nam rozwikłanie tajemnic otaczającej nas rzeczywistości i zapanowanie nad nią. Nie ma więc miejsca na współdziałanie. Indywidualizm oznacza tu nie tyle upodmiotowienie jednostki, ile uczynienie $z$ niej istoty $\mathrm{w}$ pewnym sensie samowystarczalnej, dla której doświadczenia innych są absolutnie zbędne ${ }^{34}$. To w tej właśnie ideowej tradycji indywidualizmu należy poszukiwać źródeł „utopii dionizyjskiej”. To $z$ tej tradycji filozoficznej wywodzi się choćby Stirnerowski Jedyny, który stanowi doskonałe zobrazowanie tego właśnie myślenia. „Dlaczego nie chcecie zebrać się na odwagę i samych siebie uczynić najważniejszą sprawą? - pyta niemiecki filozof. Po cóż uganiać się za wolnością, mrzonką naszą? Czyż nie Wy sami jesteście swoim marzeniem? Nie uciekajcie się więc do marzeń, wyobrażeń czy pojęć, bo wszystko to "pusta teoria». Pytajcie się o Siebie i Siebie pytajcie, bo to praktyczne, a Wy przecież chcecie być "praktyczni». [...] Przeto zwróćcie się raczej do Siebie, nie do swoich bogów czy bożków. Wydobądźcie z Was to, co w Was tkwi, ujawnijcie to, objawcie Siebie" 35.

We współczesnej kulturze i życiu społecznym zarysowała się — jak dowodzi Zygmunt Bauman - zupełnie nowa forma refleksji. Nastąpiło mianowicie odejście od funkcjonalistycznego postrzegania uniwersum społecznego. Charakteryzowało je przekonanie, że każdy element życia społecznego pełni jakieś funkcje, wywiera jakiś wpływ, jest istotny z punktu widzenia funkcjonowania całego systemu. Innymi słowy, wizja ta zakładała istnienie jakiegoś „punktu wspólnego", w którym zbiegają się różne indywidualne i grupowe cele, doświadczenia i projekty. Schemat ten odzwierciedlał właśnie ów model indywidualizmu, który przez Hayeka był określany mianem prawdziwego, a w którym to właśnie wolne jednostki są otwarte na współpracę i porozumienie w poszukiwaniu nowych dróg rozwoju intelektualnego i moralnego.

Nowa, ponowoczesna forma refleksji zaś - gdyby chcieć obrazowo ją przedstawić - odznacza się zanikiem owego „punktu wspólnego”. Drogi refleksji ludzkiej prowadzą ku indywidualnemu doświadczeniu, przeżyciu. Niejako uległy rozproszeniu. Skoro więc nie istnieje społeczeństwo, a w każdym razie dotknął je daleko posunięty proces rozmycia, trudno szukać jakiegoś elementu

33 S. Lukes, Individualism: Key Concepts in the Social Sciences, Blackwell, Oxford 1985, s. 149.

34 Por. F. Hayek, Indywidualizm i porzadek ekonomiczny, cyt. wyd., s. 15.

35 M. Stirner, Jedyny i jego własność, tłum. J. i A. Gajlewiczowie, Wydawnictwo Naukowe PWN, Warszawa 1995, s. 188. 
budującego czy określającego wspólnotę ${ }^{36}$. Podobnie jak cała rzeczywistość, tak i wszelkiego rodzaju wizje ładu społecznego w postmodernistycznej perspektywie jawią się jako płynne i nieokreślone. Nie tylko niepodobna znaleźć żadnej ich wspólnej płaszczyzny, ale przede wszystkim zatraciły one swą spójność i jednoznaczność. Wszelkie dążenia do całościowego ujęcia rzeczywistości są uznawane za zamach na suwerenność i niepowtarzalność tego, co jedyne, swoiste i niepowtarzalne. Wszak to, co jedynie realne, to świat przeżyć ludzkich, którego nie sposób ująć w jakiekolwiek reguły czy schematy. „Zapłaciliśmy dostatecznie dużo - powiada Lyotard - za tęsknoty za całością i jednością, za pojednaniem pojęcia ze zmysłowością, za przejrzystym i komunikowalnym doświadczeniem. Spod powierzchni ogólnego postulatu rozprzężenia i pojednania ciągle dobiega nas pomruk pragnienia, by zaprowadzić terror, spełnić mrzonkę ogarnięcia rzeczywistości. Nasza odpowiedź brzmi: wydać wojnę całości, dawać świadectwa tego, co nie daje się przedstawić, aktywizować poróżnienia, ratować honor poszczególnego imienia" 37 . Skończył się więc ostatecznie czas poszukiwania i wcielania w życie takiego czy innego projektu. W świecie ponowoczesnym nie ma miejsca na jakąkolwiek całościową ideę przeobrażenia społeczeństwa, nie ma celu, do którego jako społeczeństwo zdążamy, nie istnieje więc żadna wizja przyszłości. Żyjemy, jak twierdzą postmoderniści, w epoce „końca historii”, a to oznacza, że nie możemy już formułować i zmierzać ku jakiejś nowej, lepszej formie życia społecznego. Świat ponowoczesny tym różni się od „przedponowoczesnego”, że miejsce jakiegoś jednego celu i określonego projektu, który miał doń prowadzić, zajęła mnogość jednostkowych celów i dążeń, które nie mają już żadnego wspólnego mianownika. „Projektowanie i zabiegi, jakich spełnianie projektów wymaga, uległy prywatyzacji, deregulacji i fragmentaryzacji — pisze Bauman. - Zajęci jesteśmy, jak dawniej, rozwiązywaniem problemów i załatwianiem spraw - ale ani nasze zajęcia, podejmowane $\mathrm{w}$ pojedynkę czy grupowo, ani same sprawy czy problemy, jakich dotyczą, nie składają się w całość, a nadto, co najważniejsze, nie ma wśród nich "problemu problemów», metaproblemu, "problemu jak skończyć z problemami» [...]"38.

Przemiana ta oznacza zanik kumulatywnej wizji historii, zarówno w aspekcie społecznym, jak i indywidualnym. Innymi słowy, zarówno dzieje ludzkich społeczności, jak biografie jednostek dokonywały się w ramach jakiegoś „projektu”, dążyły do jego realizacji. Życie „dobre”, „spełnione” czy „szczęśliwe” oznaczało realizację tego projektu, a w każdym razie zbliżenie się do celu, który on wyznaczał. Mechanizm historii jawił się jako nieustanne poszukiwa-

36 Por. Z. Bauman, Teoria ponowoczesności - teoria $w$ ponowoczesności, w: O szansach i pułapkach ponowoczesnego świata. Materiaty z seminarium Profesora Zygmunta Baumana w Instytucie Kultury (jesień 1995-wiosna 1996), A. Zeidler-Janiszewska (red.), Instytut Kultury, Warszawa 1997, s. 35-36.

37 J.-F. Lyotard, Postmodernizm dla dzieci, cyt. wyd., s. 28.

38 Z. Bauman, Ciato i przemoc w obliczu ponowoczesności, Uniwersytet Mikołaja Kopernika, Toruń 1995, s. 19. 
nie nowych, lepszych form życia, odnajdywanie słabości istniejącego systemu społecznego po to, by zastąpić go innym, w mniemaniu ich twórców lepszym. „Dążenie do celu” i „realizowanie projektu” zastępuje w społeczeństwie ponowoczesnym swoiste ścieranie się mnogości najróżniejszych projektów. Co więcej, ścieranie to nie prowadzi do wyłonienia się jakiejkolwiek spójności i jednorodności, przeciwnie - istotą ponowoczesności jest stan nieustannej gry, zmienności, różnorodności, wieloznaczności i nieokreśloności. Słowem pluralizm ów nie jest drogą do celu, lecz emanacją dążenia do celów różnych, odrębnych i całkowicie od siebie niezależnych. Nie wykraczają one więc poza sferę doznań i odczuć jednostkowych. Całość, która może, choć bynajmniej nie musi być dla jednostki zrozumiała, to jedynie jej świat indywidualny. Wszystko, co poza sferę tę wykracza, nie jest porządkiem i ku porządkowi nie zmierza. $\mathrm{W}$ czym zatem przejawia się to indywidualne formułowanie projektów i poszukiwanie celów? Jakie są konsekwencje zaniku wspólnego metaprojektu? Jak jednostka radzi sobie w obliczu wszechobecnej ambiwalencji i „płynności”, w sytuacji „wojny, która wydana została całości”?

W tym kontekście należy przede wszystkim zwrócić uwagę na zanik tożsamości jednostki i zastąpienie jej identyfikacją. Czym różnią się od siebie te dwie kategorie? Tożsamość jest pewnym trwałym zakorzenieniem, które pozwala określić człowiekowi jego miejsce w świecie i relację do innych. Tożsamość innymi słowy to odpowiedź na pytanie: kim jestem?, jakie jest moje miejsce w otaczającym mnie świecie? Identyfikacja natomiast tym różni się od tożsamości, że ma charakter niekończącego się procesu. Nie wyrasta ona z jakichkolwiek trwałych punktów odniesienia ani do ukształtowania takowych nie prowadzi. Relacja jednostki w stosunku do otaczającego ją świata jest więc zawsze tymczasowa i zmienna. Identyfikacja jest zawsze tylko „na chwilę”, „W danej sytuacji”; jest — jak pisze Bauman — „względna i zdana na przygodność” 39 .

Zastąpienie tożsamości przez nieustannie zmienne identyfikacje kształtuje tedy pewien specyficzny sposób życia jednostki. Życie staje się nieustannym dyskursem. Poprzez dyskurs bowiem dokonuje się proces ciągłego odczytywania relacji wobec innych i odnajdywania przez człowieka swego miejsca w świecie. Oznacza to zatem stan permanentnego poczucia niepewności i wszechobecnego ryzyka. Egzystencja ludzka w warunkach ponowoczesności jest pozbawiona wszelkich trwałych punktów odniesienia. Zanik tożsamości oznacza konieczność nieustannego „zaczynania od nowa”, ciągłego dokonywania wyboru. Życie staje się nie tyle „pielgrzymim” dążeniem do celu, ile raczej niekończącym się poszukiwaniem nowych dróg, właściwym „nomadzie” 40 . „Dotarcie na

39 Z. Bauman, Tożsamość - jaka byta, jest i po co?, w: Wokót problemów tożsamości, A. Jawłowska (red.), Uniwersytet Warszawski, Instytut Stosowanych Nauk Społecznych, Warszawa 2001, s. 13; por. także: Z. Bauman, Śmierć i nieśmiertelność. O wielości strategii życia, tłum. N. Leśniewski, Wydawnictwo Naukowe PWN, Warszawa 1998, s. 197-198.

40 Por. Z. Bauman, Śmierć i nieśmiertelność, cyt. wyd., s. 199-200. 
miejsce, ostateczny kres wybierania — pisze Bauman — przeraża dużo bardziej niż perspektywa jutrzejszych wyborów, które unieważniają wybory dokonane dziś. Upragnione jest tylko pragnienie — zaspokojenie w żadnym razie" ${ }^{41}$.

Zastąpienie tożsamości przez identyfikację ma swoje niezwykle istotne konsekwencje w sferze makrospołecznej. Albowiem poczucie niepewności i ryzyka towarzyszące jednostce stało się zasadniczą cechą współczesnej kultury. Czymś, co ją przenika i kształtuje. Brak jakichkolwiek trwałych reguł, punktów odniesienia i uniwersalnych celów sprawia, iż nie tylko staje się ona domeną niepewności, ale także traci wewnętrzną spójność i logikę. Brak jednorodnego celu, projektu czy wspólnego ideału, który konstytuowałby wewnętrzny porządek życia społecznego, zostaje zastąpiony dążeniem do szybkiego i maksymalnie efektywnego zaspokojenia doraźnych potrzeb czy pragnień. Postmodernistyczna postawa odrzuca nie tylko strategię małych kroków - stopniowego dochodzenia do wyznaczonego celu. Nie ma w niej miejsca na jakiekolwiek działania długofalowe, nastawione na wyrzeczenie czy czekanie na dogodną sytuację. Skoro bowiem nie istnieje nic, co dawałoby poczucie trwałości, działanie jednostki zaczyna być ukierunkowane na to, co „tu i teraz”, w danym momencie może przynieść jej możliwie najwięcej korzyści i satysfakcji. Bauman postawę tę nazywa „kulturą kasyna”, widząc w niej podobieństwo do hazardu. Ryzyko, ulotność i płytkość więzi międzyludzkich, instrumentalne wykorzystywanie człowieka, brak długofalowej i racjonalnej kalkulacji własnych działań w imię pewnych ideałów - wszystko to składa się na całość postawy, której głównym celem jest pogoń za „przeżyciem”, „zachwytem”, „zaspokojeniem” i „oczarowaniem” 42 . Z tego punktu widzenia daje się zauważyć znacząca przemiana człowieka. Bauman mówi o zaniku pewnego jego profilu, który określa mianem „dostarczyciela dóbr”. Jego miejsce zajął „poszukiwacz przeżyć”. Życie tego pierwszego dokonuje się zawsze w kontekście życia innych ludzi. To „z nimi”, „dzięki nim” i „dla nich” wykonuje się swoją pracę, a takie czy inne korzyści stąd płynące postrzegane są jako efekt owej pracy - coś wobec niej wtórnego, pewna należność czy nagroda. „Poszukiwacz przeżyć” natomiast traktuje innych wyłącznie jako środek do tego zasadniczego swego celu, jakim jest poczucie spełnienia czy zaspokojenie pragnień. Owo „przeżycie” staje się najważniejszym celem człowieka, celem, który jednak nie staje się elementem jakiegoś większego „projektu” dobrego życia. Ma zawsze wymiar absolutnie indywidualny. Jeżeli nie koliduje z działaniami innych jednostek, to pozostaje zawsze w sferze doświadczeń samoistnej jednostki. Nie ma tu już miejsca na wzajemność i współpracę w imię jakichś wspólnych dążeń ${ }^{43}$. „W związku z tym, że upadła nadzieja, żywiona przez większość nowoczesnych

41 Z. Bauman, Tożsamość..., cyt. wyd., s. 18.

42 Por. Z. Bauman, Życie na przemiał, tłum. T. Kunz, Wydawnictwo Literackie, Kraków 2004, s. 182-203.

43 Por. Z. Bauman, Ciało i przemoc..., cyt. wyd., s. 102-109. 
doktryn filozoficznych — pisze Bauman — nadzieja, że prędzej czy później uda się wspólnym wysiłkiem administracji i władz intelektualnych wyeliminować przypadkowość, losowość i żywiołowość z obszaru ludzkiego doświadczenia - jednym twardym i godnym zaufania punktem wyjścia dla teorii stało się doznanie, doświadczenie, słowem, ludzkie przeżycia" 44 .

Czas więc, by odpowiedzieć na pytania sformułowane na początku. Na czym polega owa „śmierć utopii”? Patrząc na kształt, jaki przybrała postmodernistyczna idea, łatwo zauważyć znaczący paradoks. Cała europejska tradycja myśli społecznej naznaczona była poszukiwaniem nowych, lepszych form życia społecznego. Niezależnie, czy była to wizja chrześcijańskiej wspólnoty politycznej, powrotu do republikańskich tradycji rzymskich, zbudowania ustroju zgodnego z prawami natury czy wreszcie projekt racjonalnie urządzonego społeczeństwa uwolnionego od wszelkich „przesądów”, zawsze mieliśmy do czynienia właśnie z jakimś „projektem”, taką czy inną „wielką narracją” kształtującą horyzont intelektualny i etyczny ludzi danego czasu. Zwłaszcza oświeceniowa tradycja filozoficzna oraz idee socjalistyczne i komunistyczne XIX wieku ukształtowały pewną wizję społeczeństwa, w którym nastąpić miało „spełnienie dziejów”. Dostrzegamy to choćby w teorii postępu Condorceta, ale najsilniej przekonanie takie dało o sobie znać w marksizmie. To właśnie wizja społeczeństwa wyłaniającego się z rewolucji proletariackiej stanowi najwymowniejszy przykład przekonania o możliwości stworzenia doskonałego porządku ostatecznego. Logika utopii polega więc na tym, że owa funkcja krytyczna, będąc tym samym siłą kreującą nowy ład społeczny, niesie przekonanie o rychłym „końcu utopii”. Rzeczywistość, która powstanie w mniej czy bardziej odległej przyszłości, nie będzie już wymagała ani krytyki, ani tym samym poszukiwania i tworzenia nowego projektu.

Wspomniany paradoks polega więc na tym, że postmodernizm doprowadza niejako do spełnienia to przekonanie. Czyni to jednak w sposób diametralnie odmienny od tego, jaki wyobrażali sobie twórcy owych projektów. „Śmierć utopii" nastąpiła bowiem w wyniku nie realizacji dążeń i celów im przyświecających, lecz uznania bezsensowności formułowania wszelkich całościowych wizji i poszukiwania dróg ich realizacji. Działania takie, jak wskazują postmoderniści, nie uczyniły świata lepszym, człowieka etycznie doskonalszym czy żyjącym w poczuciu spełnienia. Ponowoczesność bowiem, wskazując na nieusuwalność niepewności i wieloznaczności z naszego życia, ostatecznie neguje podstawy tego rodzaju ambicji i dążeń. Zagubienie i niepewność są nieodłącznymi towarzyszami egzystencji ludzkiej. I choć jednostka poszukuje trwałych drogowskazów i punktów odniesienia, to nigdy nie zaspokoją one jej oczekiwań. Dadzą jedynie iluzję ładu, a w ślad za nim iluzję świata prostego i jednoznacznego. Skazani więc jesteśmy na postawę sceptyka, który nie ma już ambicji tworzenia nowego ładu ani złudzeń, że takowy ład można zbudować.

44 Z. Bauman, Teoria ponowoczesności..., cyt. wyd., s. 36. 
Sceptyk ów żyje w przekonaniu, że to, co jest, jest zawsze ulotne i niepewne, jest prawdą tymczasową i „tylko dla niego”. I choć jest to dla niego „źródło cierpień”, to żyje ze świadomością, że nie da się świata inaczej urządzić. „Ponowoczesna krytyka zamierzeń nowoczesności jest [...] — jak stwierdza Bauman - ostatecznym triumfem nowoczesnego ducha. Ostatnia bariera ustawiona przed umysłem krytycznym, jaką było jedyne nie zeświecczone jeszcze sacrum, przyszłe Królestwo Rozumu - ustąpiła w końcu pod naporem tępicieli iluzji. Pod obstrzałem dział, odlanych do kruszenia iluzji, znalazły się dziś iluzje, w imię których je odlewano...” 45 . „Śmierć utopii” jawi się zatem w perspektywie postmodernistycznej w sposób szczególny. Ma ona bowiem swe źródło nie tylko w odrzuceniu wszelkiego konstruktywizmu, który nakazywał poszukiwanie optymalnych form owej społecznej konstrukcji. Odrzucenie de facto samej kategorii społeczeństwa czyni taką refleksję całkowicie bezpodstawną.

Nie oznacza to jednak, że postmodernistyczny sceptycyzm ostatecznie pogrzebał utopijne poszukiwania. Zmienił on jedynie pewną formę utopijnej refleksji, przenosząc ją niejako w inne miejsce. Starałem się tu pokazać, że pewne istotne elementy myślenia utopijnego funkcjonują w sferze współczesnej kultury, w dużej mierze kształtowanej przez postmodernistyczną filozofię. Można oczywiście zastanawiać się, czy owe dążenia do uzyskania indywidualnej satysfakcji, spełnienia, samorealizacji, zdrowia i urody stanowią jeszcze utopię, czy też mamy do czynienia z jakąś nową, inną formą ludzkiej refleksji i dążeń. Niewątpliwie bowiem nie znajdujemy tu już ani całościowego projektu nowej rzeczywistości ani trwałego celu dążeń. Trudno mówić też o jej aspekcie krytycznym czy regulatywnym. Wszak w „płynnym” świecie ponowoczesności trudno cokolwiek poddawać ocenie czy nadawać rzeczywistości jakiś określony kształt. Jednakże owe dążenia obserwowane dziś na poziomie zachowań jednostkowych, które w zasadniczy sposób kształtują współczesną kulturę, naznaczone są pewnymi cechami właściwymi utopii. Ta „utopia dionizyjska” dlatego jest utopią, że obecne jest w niej to, co dla myślenia utopijnego jest konstytutywne - mianowicie dążenie do odnalezienia sposobu „dobrego życia”. Choć nie przyjmuje on już postaci uniwersalnego modelu, to sam ów mechanizm poszukiwania nie przestał istnieć. Sceptycyzm postmodernistów co do możliwości stworzenia i realizacji „projektu” nie oznacza bowiem sceptycyzmu co do poszukiwania indywidualnych dróg samorealizacji. A zatem owo napięcie między tym „jak jest” a tym „jak być powinno” nie zanikło, zmieniło jedynie swój charakter. Co więcej, mimo iż uległy zanikowi wszelkie uniwersalne cele zmiany społecznej, to te indywidualne strategie poszukiwania szczęścia nie stanowią jednak czysto indywidualnego wyboru. Możemy mówić wręcz o pewnym dogmatyzmie utopii czasów postmodernizmu, który nie jest wcale mniejszy aniżeli dogmatyzm tradycyjnych utopii społecznych. Przyjmuje on jedynie inną postać. O ile bowiem przeświadczenie o konieczności wprowadzenia w życie

45 Z. Bauman, Ciało i przemoc..., cyt. wyd., s. 24. 
utopijnego projektu nowego ładu społecznego częstokroć przyjmowało formę przemocy $\mathrm{w}$ aspekcie instytucjonalno-politycznym, o tyle tutaj środki formalnoprawne zostały zastąpione przez to, co Bourdieu określa mianem „przemocy symbolicznej”. Cała sieć reklamy i szeroko rozumianego przekazu medialnego tworzy wszechobecną w istocie siłę propagującą i narzucającą określoną modę, styl życia, wartości i normy postępowania ${ }^{46}$. Choć nie są one usankcjonowane przez wskazania rozumu, historyczną konieczność czy „nagą” siłę, to przekaz, iż „tak robią wszyscy”, okazuje się nie mniej skuteczny czy łatwiejszy do podważenia.

Także ów religijny, czy raczej quasi-religijny charakter utopii nie zaniknął, uległ jedynie istotnej przemianie. Dokładnie rzecz ujmując, miejsce dyskursu, który w poszukiwaniach ładu doskonałego odwoływał się do kategorii religijnych, czy też kategorie te poddawał swoistej reinterpretacji, zajął dyskurs o charakterze medycznym. Inaczej mówiąc, językiem medycznym opisuje się dziś to odwieczne, właściwe utopii dążenie do szczęścia. Zdrowie, uroda, witalność, słowem stan fizycznej i psychicznej sprawności, stają się synonimem stanu owej szczęśliwości i spełnienia. A utopijne dążenie do ostatecznego odkrycia „tajemnicy” oznacza „wejście w siebie”, samopoznanie. „Oswojenie” i podporządkowanie sobie świata przejawia się $\mathrm{W}$ próbach pełnego wniknięcia w wewnętrzny świat jednostki, swoisty podbój mikrokosmosu, który każda jednostka stanowi sama dla siebie. Mamy do czynienia ze „zmianą zasady integrującej system społeczny" 47 .

Utopijna eschatologia ostatecznego spełnienia oznaczała chęć zbudowania takiej czy innej wersji społeczeństwa doskonałego. Dążenie to było tedy próbą ostatecznego odkrycia tajemnicy, usunięcia wszelkiej niepewności stojącej przed człowiekiem. Utopijne zwieńczenie historii było projektem całkowicie "przejrzystym”, w pełni ludzkiemu rozumowi dostępnym. Utopia „dionizyjska” także uchyla wszelką „tajemniczość” świata. Czyni to jednak już nie na drodze intelektualnych czy duchowych poszukiwań, lecz przez pomijanie pytań, które mogłyby zburzyć owo ulotne poczucie satysfakcji. Postmodernistyczny sceptycyzm każe nie zauważać tego, co jest „problemem”, w przekonaniu, że skoro nie znajdziemy żadnej ostatecznej odpowiedzi, lepiej stworzyć iluzję, w której dobre samopoczucie jednostki nie zostanie zakłócone. Utopijne poszukiwanie szczęścia i spełnienia przybiera więc postać nie tyle „dążenia do celu”, ile raczej nieustannej pogoni za celami zmiennymi i ulotnymi, które w danej chwili wydają się atrakcyjne. Diagnozę „śmierci utopii” należy zatem rozumieć jako zanik jedynie pewnego jej typu, modelu. Sama istota utopijnego myślenia,

46 Por. P. Bourdieu, J.-C. Passeron, Reprodukcja. Elementy teorii systemu nauczania, tłum. E. Neyman, Wydawnictwo Naukowe PWN, Warszawa 2006, s. 71-150; por. także: P. Bourdieu, Dystynkcja. Społeczna krytyka władzy sądzenia, tłum. P. Biłos, Scholar, Warszawa 2005, s. 447.

47 Zob. M. Jacyno, Kultura indywidualizmu, Wydawnictwo Naukowe PWN, Warszawa 2007, s. 11-12 . 
polegająca na nieustannym poszukiwaniu nowych form życia, jednak nie zanikła, przeciwnie - nic nie straciła ze swej intensywności, choć w całkowicie innej niż dotychczas postaci. Jakaś forma myślenia utopijnego, polegająca na poszukiwaniu tego, ,jak być powinno”, jest bowiem niezbędna nie tylko dla życia społecznego w jego klasycznym rozumieniu, ale w nie mniejszym stopniu także dla życia indywidualnego. Może to właśnie na drodze rozwoju swej indywidualności człowiek współczesny lepiej odnajduje cele swych poszukiwań, aniżeli pozwalały mu na to wielkie społeczne projekty? Może w ten sposób właśnie pełniej ukazuje się to — by raz jeszcze przywołać Paula Tillicha — kim człowiek jest w swej istocie i co musi posiadać, by spełnić się jako osoba?

\section{IS OUR TIME THAT OF “THE DEATH OF UTOPIA?”}

\section{Summary}

The article concerns the problem of the crisis of utopia. Many philosophers and social scientists speak about "the death of utopia". This opinion is closely related to the theory of "the end of ideology", which was very popular after World War II. Researchers often show that great projects envisaging a radical transformation of society have revealed their destructive power. Moreover, contemporary culture, and especially post-modernist philosophy place emphasis on the temporariness, instability and "liquidity" of the scheme of social life. So they leave no room for the constitutive elements of utopian thinking: the overall and enduring projects of the construction of a perfect social order. The article poses the basic question: are utopian ideas completely absent from the post-modernist vision of society, or do those ideas assume a different character? The author shows some elements of utopian thinking existing at the level of individual culture. Utopia in its traditional sense has completely disappeared. This does not mean, however, that there is no form of utopian reflection in contemporary post-modernist society. It appears in a completely new form: the search for a perfect social order has been replaced by a multitude of various ways of looking for a perfect life in the individual dimension.

\section{Key words/słowa kluczowe}

utopia / utopia; crisis / kryzys; postmodernism / postmodernizm; individualism / indywidualizm 